MAKALAH

\title{
STANDAR ISI PENDIDIKAN
}

Diajukan Sebagai Salah Satu Tugas Uts Mata Kuliah Manajemen Sekolah

\section{Dosen :}

Wahyu Bagja Sulfemi, M.pd

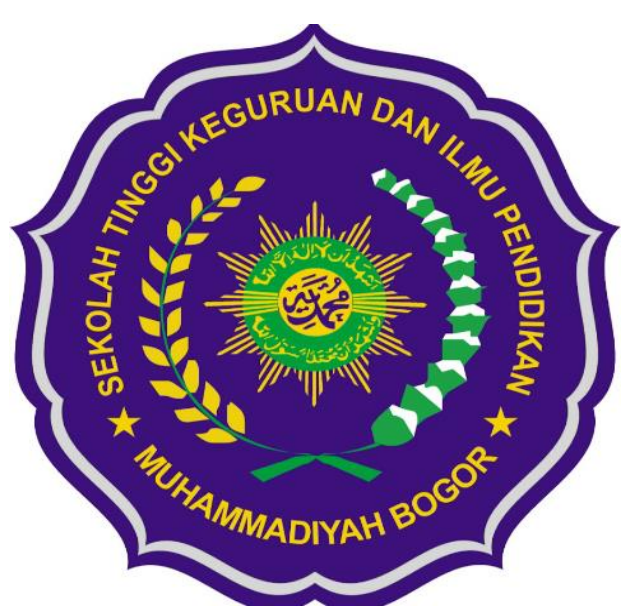

Disusun oleh:

Reni Rensiana

0142S1A018020

Semester 3 (tiga)

PROGRAM STUDI ADMINISTRASI PENDIDIKAN

STKIP MUHAMMADIYAH BOGOR 


\begin{abstract}
ABSTRAK
Standar Isi yang merupakan kriteria mengenai ruang lingkup materi dan tingkat kompetensi peserta didik untuk mencapai kompetensi lulusan pada jenjang dan jenis pendidikan tertentu. Untuk memenuhi kebutuhan masa depan dan menyongsong Generasi Emas Indonesia Tahun 2045, telah ditetapkan Standar Kompetensi Lulusan yang berbasis pada Kompetensi Abad XXI, Bonus Demografi Indonesia, dan Potensi Indonesia menjadi Kelompok 7 Negara Ekonomi Terbesar Dunia, dan sekaligus memperkuat kontribusi Indonesia terhadap pembangunan peradaban dunia.
\end{abstract}




\section{STANDAR ISI PENDIDIKAN}

\section{A. Pengertian Standar Isi}

Standarisi pendidikan adalah mencakup lingkup materi dan tingka t kompetensi untuk mencapai kompetensi lulusan dan jenis pendidika n tertentu. Standar isi memuat krangka dasar dan struktur kurikulum, beban belajar, kurikulum tingkat satuan pendidikan,dan kalender pendidikan/akademik.

\section{B. Kelompok Mata Pelajaran dan Kedalaman Isi}

Standar isipendidikan mengatur kerangka dasar kurikulum, beban belajar, kalender akademik, dan kurikulum tingkat satuan pendidikan. Standar isi mencakup lingkup dan kedalaman materi pembelajaran untuk memenuhi standar kompetensi lulusan. Kurikulum SDBI terdiri dari: kelompok mata pelajaran agama dan akhlak mulia; kelompok mata pelajaran kewarganegaraan dan kepribadian; kelompok mata pelajaran ilmu pengetahuandan teknologi;kelompok m ata pelajaran estetika; dan kelompok mata pelajaran jasmani, olahrag a,dan kesehatan.

Setiap kelompok mata pelajaran dilaksanakan secara holistik sehingga pembelajaran masing-masing kelompok mata pelajaran ikut mewarnai pemahaman dan penghayatan peserta didik.

\section{Pasal Tentang Standar Isi Satuan Pendidikan}

Pasal 1

(1) Standar Isi untuk Pendidikan Dasar dan Menengah yang selanjutnya disebut Standar Isi mencakup lingkup materi minimal dan tingkat kompetensi minimal untuk mencapai kompetensi lulusan minimal pada jenjang dan jenis pendidikan tertentu.

(2) Standar Isi untuk muatan peminatan kejuruan pada SMK/MAK/Paket

C Kejuruan pada setiap program keahlian diatur dalam Peraturan Direktur Jenderal Pendidikan Menengah. 
(3) Standar Isi sebagaimana dimaksud pada ayat (1) tercantum pada Lampiran yang merupakan bagian yang tidak terpisah dari Peraturan Menteri ini.

\section{Pasal 2}

Dengan berlakunya Peraturan Menteri ini, satuan pendidikan dasar dan menengah wajib menyesuaikan dengan Peraturan Menteri ini paling lambat 3 (tiga) tahun untuk semua tingkat kelas.

\section{Pasal 3}

Pada saat berlakunya Peraturan Menteri ini Peraturan Menteri Pendidikan Nasional Nomor 22 Tahun 2006 tentang Standar Isi untuk Satuan Pendidikan Dasar dan Menengah dicabut dan dinyatakan tidak berlaku. Peraturan ini mulai berlaku pada tanggal diundangkan. Agar setiap orang mengetahuinya, memerintahkan pengundangan Peraturan Menteri ini dengan penempatannya dalam Berita Negara Republik Indonesia.

Undang-Undang Dasar Negara Republik Indonesia Tahun 1945 Pasal 31 ayat (3) mengamanatkan bahwa Pemerintah mengusahakan dan menyelenggarakan satu sistem pendidikan nasional, yang meningkatkan keimanan dan ketakwaan serta akhlak mulia dalam rangka mencerdaskan kehidupan bangsa, yang diatur dengan undang-undang. Atas dasar amanah tersebut telah diterbitkan Undang-Undang Republik Indonesia Nomor 20 Tahun 2003 tentang Sistem Pendidikan Nasional.

Dasar, fungsi, dan tujuan pendidikan nasional menurut UndangUndang Republik Indonesia Nomor 20 Tahun 2003 tentang Sistem Pendidikan Nasional bahwa pendidikan nasional berdasarkan Pancasila dan Undang-Undang Dasar Negara Republik Indonesia Tahun 1945 (Pasal 2), berfungsi mengembangkan kemampuan dan membentuk watak serta peradaban bangsa yang bermartabat dalam rangka mencerdaskan kehidupan bangsa, bertujuan untuk mengembangkan potensi peserta didik agar menjadi manusia yang beriman dan bertakwa kepada Tuhan Yang 
Maha Esa, berakhlak mulia, sehat, berilmu, cakap, kreatif, mandiri, dan menjadi warga negara yang demokratis serta bertanggung jawab (Pasal 3).

Implementasi Undang-Undang Nomor 20 tahun 2003 tentang Sistem Pendidikan Nasional dijabarkan ke dalam sejumlah peraturan, diantaranya adalah Peraturan Pemerintah Nomor 19 Tahun 2005 tentang Standar Nasional Pendidikan dan Peraturan Pemerintah Nomor 32 Tahun 2013 tentang Perubahan atas Peraturan Pemerintah Nomor 19 Tahun 2005 tentang Standar Nasional Pendidikan. Peraturan pemerintah tersebut memberikan arahan tentang perlunya disusun dan dilaksanakan delapan standar nasional pendidikan, yaitu: standar isi, standar proses, standar kompetensi lulusan, standar pendidik dan tenaga kependidikan, standar sarana dan prasarana, standar pengelolaan, standar pembiayaan, dan standar penilaian pendidikan.

Dalam upaya mewujudkan tujuan pendidikan nasional tersebut telah ditetapkan Standar Kompetensi Lulusan yang merupakan kriteria mengenai kualifikasi kemampuan lulusan yang mencakup sikap, pengetahuan, dan keterampilan. Untuk mencapai kompetensi lulusan tersebut perlu ditetapkan Standar Isi yang merupakan kriteria mengenai ruang lingkup materi dan tingkat kompetensi peserta didik untuk mencapai kompetensi lulusan pada jenjang dan jenis pendidikan tertentu. Untuk memenuhi kebutuhan masa depan dan menyongsong Generasi Emas Indonesia Tahun 2045, telah ditetapkan Standar Kompetensi Lulusan yang berbasis pada Kompetensi Abad XXI, Bonus Demografi Indonesia, dan Potensi Indonesia menjadi Kelompok 7 Negara Ekonomi Terbesar Dunia, dan sekaligus memperkuat kontribusi Indonesia terhadap pembangunan peradaban dunia.

\section{Ruang Lingkup Materi}

Ruang lingkup materi dan tingkat kompetensi peserta didik yang harus dipenuhi atau dicapai pada suatu satuan pendidikan dalam jenjang dan jenis pendidikan tertentu dirumuskan dalam Standar Isi untuk setiap mata pelajaran. 
Standar Isi disesuaikan dengan substansi tujuan pendidikan nasional dalam domain sikap spiritual dan sikap sosial, pengetahuan, dan keterampilan. Oleh karena itu, Standar Isi dikembangkan untuk menentukan kriteria ruang lingkup dan tingkat kompetensi yang sesuai dengan kompetensi lulusan yang dirumuskan pada Standar Kompetensi Lulusan, yakni sikap, pengetahuan, dan keterampilan. Karakteristik, kesesuaian, kecukupan, keluasan, dan kedalaman materi ditentukan sesuai dengan karakteristik kompetensi beserta proses pemerolehan kompetensi tersebut. Ketiga kompetensi tersebut memiliki proses pemerolehan yang berbeda. Sikap dibentuk melalui aktivitas-aktivitas: menerima, menjalankan, menghargai, menghayati, dan mengamalkan.

Pengetahuan dimiliki melalui aktivitas-aktivitas: mengetahui, memahami, menerapkan, menganalisis, mengevaluasi, dan mencipta. Keterampilan diperoleh melalui aktivitas-aktivitas: mengamati, menanya, mencoba, menalar, menyaji, dan mencipta. Karakteristik kompetensi beserta perbedaan proses pemerolehannya mempengaruhi Standar Isi.

Berdasarkan Peraturan Pemerintah Nomor 19 tentang Standar Nasional Pendidikan sebagaimana telah diubah dengan Peraturan Pemerintah Nomor 32 Tahun 2013 tentang Perubahan Atas Peraturan Pemerintah Nomor 19 tentang Standar Nasional Pendidikan ditetapkan bahwa Standar Isi adalah kriteria mengenai ruang lingkup materi dan tingkat kompetensi untuk mencapai kompetensi lulusan pada jenjang dan jenis pendidikan tertentu. Ruang lingkup materi dirumuskan berdasarkan kriteria muatan wajib yang ditetapkan sesuai ketentuan peraturan perundang-undangan, konsep keilmuan, dan karakteristik satuan pendidikan dan program pendidikan. Selanjutnya, tingkat kompetensi dirumuskan berdasarkan kriteria tingkat perkembangan peserta didik, kualifikasi kompetensi Indonesia, dan penguasaan kompetensi yang berjenjang.

Prinsip Pengembangan Kurikulum Kurikulum tingkat satuan pendidikan jenjang pendidikan dasar dan menengah dikembangkan oleh sekolah dan komite sekolah berpedoman pada standar kompetensi lulusan 
dan standar isi serta panduan penyusunan kurikulum yang dibuat oleh BSNP. 


\section{DAFTAR PUSTAKA}

http://makalahpendidikan-sudirman.blogspot.com/2011/11/8.html

http://bsnp-indonesia.org/standar-isi/

Sulfemi,Wahyu Bagja .(2018). MANAJEMEN KURIKULUM DI SEKOLAH,

Modul Pembelajaran Program Studi Administrasi Pendidikan STKIP

Muhammadiyah Bogor. 


\section{SOAL}

\section{PG}

1. manajemen adalah ilmu dan seni mengatur proses pemanfaatan sumber daya manusia dan sumber-sumber lainnya secara efektif dan efisien untuk mencapai tujuan tertentu. Merupakan definisi yang dikemukakan oleh ....

a. Rusman

b. Teguh

c. Hamalik

d. Malayu SP

2. suatu sistem pengelolaan kurikulum yang kooperatif, komperhensif, sistemik dan sistematik dalam rangka mewujudkan ketercapaian tujuan kurikulum. Merupakan definisi.......

a. Manajemen

b. Kurikulum

c. Manajemen kurikulum

d. Peraturan

3. Yang termasuk ruang lingkup manajemen kurikulum adalah......

a. Evaluasi Kurikulum

b. Peta Konsep

c. Rangkuman

d. Controlling

4. Yang termasuk prinsip manajemen kurikulum kecuali...

a. Produktivitas

b. Substansi

c. Demokratisasi 
d. Kooperatif

5. Meningkatkan keadilan (equity) Termasuk dalam hal......

a. Prinsip manajemen kurikulum

b. Pengertian manajemen kurikulum

c. Fungsi manajemen kurikulum

d. Bentuk manajemen kurikulum

6. Sebutkan bentuk-bentuk manajemen kurikulum....

a. Produktivitas, Demokratisasi, Kooperatif

b. Pengertian, Ruang lingkup, Tugas

c. Perencanaan, Pengorganisasian, Pengawasan

d. subject centered curriculum, Integrated Curriculum, Core curriculum

7. Apa yang dimaksud dengan Integrated Curriculum.....

a. kurikulum yang terdiri atas mata pelajaran yang terpisah-pisah.

b. kurikulum yang diorganisasikan dalam bentuk unit-unit tanpa harus ada mata pelajaran atau bidang studi.

c. kurikulum inti yang diberikan kepada semua murid untuk mencapai keseluruhan program kurikulum secara utuh.

d. kurikulum yang disusun dengan mengkorelasikan atau menggabungkan sejumlah mata pelajaran

8. Ada berapa sebab rumusan tujuan pembelajaran tersebut harus terlebih dahulu ditetapkan?

a. tiga. c. lima

b. empat d. enam

9. Dalam melakukan penilaian ada disebut sasaran penilaian,siapakah maksud sasaran penilaian tersebut? 

a. guru
c. masyarakat

b. siswa. d. dokter

10. Ada berapa penilaian hasil belajar dalam Kurikulum Tingkat Satuan Pendidikan (KTSP) dapat dilakukan?
a. lima.
c. tujuh
b. empat d. delapan

\section{Soal Essai}

1. Menurut pendapat Nana Sudjana menjelaskan bahwa evaluasi adalah?

2. Dari uraian struktural kurikulum, ada 4 komponen utama yakni?

3. Sebutkan rumusan tujuan pembelajaran tersebut harus terlebih dahulu ditetapkan!

4. Apa yang dimaksud dengan strategi pembelajaran?

5. Sebutkan penilaian hasil belajar dalam Kurikulum Tingkat Satuan Pendidikan (KTSP) dapat dilakukan antara lain. 


\section{Kunci Jawaban Pilihan Ganda}

1. D

2. A

3. B

4. A

5. A

6. $\mathrm{C}$

7. D

8. A

9. B

10. A

\section{Kunci Jawaban Essai}

1. Adalah proses penentuan nilai sesuatu berdasarkan kriteria tertentu, yang dalam proses tersebut tercakup usaha untuk mencari dan mengumpulkan data atau informasi yang diperlukan sebagai dasar dalam menentukan nilai sesuatu yang menjadi objek evaluasi, seperti program, prosedur, usul, cara, pendekatan, model kerja, hasil program, dan lain sebagainya.

2. -Tujuan, -Isi dan struktur kurikulum, -Strategi pelaksanaan, dan lainnya, Komponen evaluasi.

3. -Tujuan berfungsi menentukan arah dan corak kegiatan pendidikan, -Tujuan menjadi indikator dari keberhasilan pelaksanaan pendidikan, -Tujuan menjadi pegangan dalam setiap usaha dan tindakan dari pelaksanaan pendidikan.

4. Cara yang digunakan untuk menyampaikan materi pelajaran dalam upaya mencapai tujuan pembelajaran. Suatu strategi pembelajaran mengandung pengertian terlaksananya kegiatan guru dan kegiatan siswa dalam proses 
pembelajaran. 5. - Penilaian kelas, - Tes kemampuan dasar, - Penilaian akhir satuan pendidikan, - Benchmarking, - Penilaian program. 